\title{
Banking Relationships of Lower-Income Families and the Governmental Trend toward Electronic Payment
}

Jeanne M. Hogarth and Kevin H. O'Donnell, of the Board's Division of Consumer and Community Affairs, prepared this article.

In the past three years, the federal government and many states have lowered their costs of administering welfare and benefits programs by expanding the use of electronic payment. These initiatives promise to have their greatest significance, and meet their greatest challenge, among lower-income families, the demographic group with the lowest rate of bank account ownership and the least familiarity with electronic transactions.

Although the payment programs do not require a banking relationship, the move to electronic transfer could change the financial practices of many recipients without a deposit account or with no banking relationship at all. Recipients of social security and other benefits payments who do not have a checking account may well continue to obtain cash and other financial services from alternative service providers, such as check cashing outlets and grocery stores. But in light of the increased promotion of direct deposit, many of these recipients may be more inclined to open a deposit account. The attraction of a bank account for some families without one may become heightened as governments and the payment system in general move more toward electronic transactions. An example of such a move is the federal government's introduction this summer of special accounts to be made available at depository institutions primarily for the transfer of federal payments.

In these ways, the governmental move to electronic payment may do more than the "basic banking" effort of the 1980s to spread the use of bank accounts to "unbanked" families. Moreover, the greater use of the banking system by these families could harmonize with the emphasis that welfare reform has placed on asset-building for lower-income families, a goal that may be harder to achieve without the use of a bank account. On the other hand, a move by greater numbers of lower-income families into the mainstream of the payment system is likely to be a difficult transition for many of them, given survey results on why they do not currently use the banking system.

This article examines the ways in which lowerincome families obtain checking and credit services, the effects that the government move to electronic payment may have on these families and on depository institutions, and the promotional and educational efforts that may be needed to facilitate the move to electronic services.

\section{OWNERSHIP OF TRANSACTION ACCOUNTS AND USE OF FINANCIAL INSTITUTIONS}

According to the Federal Reserve Board's Survey of Consumer Finances (SCF), about 87 percent of all U.S. families in 1995 had a transaction account at a financial institution. ${ }^{1}$ Most of these ( 85 percent of all families) had a checking account, and 36 percent of all families had a savings account (table 1; also see box "Account Ownership over Time"). ${ }^{2}$

1. Except as noted, data in this article are from the SCF. Details on the survey and its results are available in Arthur B. Kennickell, Martha Starr-McCluer, and Annika E. Sundén, "Family Finances in the U.S.: Recent Evidence from the Survey of Consumer Finances," Federal Reserve Bulletin, vol. 83 (January 1997), pp. 1-24; see also the survey's web site, at www.federalreserve.gov/pubs/oss/oss2/ scfindex.html. Although the present article does not directly address the statistical significance of the results presented, it highlights findings that are significant or provide insight in a broad context.

2. The SCF asks respondents whether they have a "checking account," but under the term "transaction account" the SCF also tracks ownership of a broader set of assets_ "checkable" accounts and savings accounts.

Checkable accounts consist of checking accounts and money market accounts at depository institutions, money market accounts with mutual funds, and call/cash accounts at brokerages. Savings accounts are passbook and statement savings accounts at depository institutions but not term accounts such as certificates of deposit.

Depository institutions consist of commercial banks, trust companies, thrift institutions, and credit unions. Thrift institutions consist of savings and loan associations and savings banks. See the SCF Codebook for a full listing of financial institutions covered by the SCF.

In this article, the terms "bank" and "banking" are used generically to encompass all depository institutions unless specifically limited to commercial banks. 
1. Ownership of transaction accounts and other financial products, 1995

Percent

\begin{tabular}{|c|c|c|}
\hline Product & $\begin{array}{l}\text { All U.S. } \\
\text { families }\end{array}$ & $\begin{array}{l}\text { Lower-incom } \\
\text { families }\end{array}$ \\
\hline \multicolumn{3}{|l|}{ Transaction account } \\
\hline Either checking or savings & 87.4 & 75.8 \\
\hline Checking $\ldots \ldots \ldots \ldots \ldots . . . . .$. & 85.0 & 72.1 \\
\hline Savings. & 36.0 & 25.4 \\
\hline Both checking and savings & 33.5 & 21.5 \\
\hline \multicolumn{3}{|l|}{ Credit } \\
\hline Major credit card ${ }^{1}$ & 66.5 & 44.6 \\
\hline \multicolumn{3}{|l|}{ Loan } \\
\hline Vehicle & 30.8 & 18.6 \\
\hline Education & 11.8 & 10.6 \\
\hline Consumer & 14.2 & 13.5 \\
\hline \multicolumn{3}{|l|}{ Mortgage $^{2}$} \\
\hline First & 38.7 & 18.1 \\
\hline Second $\ldots \ldots \ldots$ & 3.4 & 1.4 \\
\hline Home equity line of credit & 11.0 & 4.3 \\
\hline Memo: Owns home ....... & 64.7 & 49.6 \\
\hline \multicolumn{3}{|l|}{ Savings and investments } \\
\hline Certificate of deposit ... & 14.3 & 12.9 \\
\hline Savings bonds ....... & 22.8 & 10.6 \\
\hline IRA or Keogh account. & 26.1 & 12.1 \\
\hline Mutual fund ........... & 12.3 & 4.2 \\
\hline Stocks ............... & 15.2 & 6.7 \\
\hline Bonds & 3.1 & .6 \\
\hline Annuities & 3.2 & 2.1 \\
\hline \multicolumn{3}{|l|}{ Life insurance ${ }^{3}$} \\
\hline Any $\ldots \ldots \ldots$ & 71.9 & 55.0 \\
\hline Term & 76.0 & 71.0 \\
\hline Whole life .............. & 44.4 & 40.1 \\
\hline Both term and whole life & 20.4 & 11.1 \\
\hline
\end{tabular}

Note. Data in this and other tables in this article are from the 1995 Survey of Consumer Finances except as noted. For details and definition of lower income, see text and appendix A. For definition of transaction account and depository institution, see text note 2 .

1. Discover, MasterCard, Optima, and Visa.

2. On primary residence.

3. Percentages of respondents holding particular types are for those owning life insurance.

IRA Individual Retirement Account.

\section{Use of Financial Services by Lower-Income Families}

The median income of the 100 million families in the United States (including single-person households) for the year preceding the $1995 \mathrm{SCF}$ was roughly $\$ 32,000$. At the threshold commonly used to define low to moderate income ( 80 percent of median income), approximately 45 percent of U.S. families in 1995 , or about 45 million families, were in that category (hereafter referred to as lower income; see box "Some Characteristics of Low- to ModerateIncome Families" and appendix A). ${ }^{3}$

Of the lower-income families in the 1995 survey, about 75 percent (roughly 34 million families) had a transaction account, and 25 percent (roughly 11 mil-

3. The median income measure is for 1994 and is from the Bureau of the Census, Current Population Survey. The number of families at or beneath the 80 percent threshold is from the $1995 \mathrm{SCF}$, which asked respondents for their income in calendar year 1994 lion families) did not; about 72 percent of lowerincome families had a checking account (table 1). In addition, substantial percentages of lower-income families held an array of other financial products including loans, investments, and life insurance, some of which may have involved a relationship with a depository institution. Hence many of the 11 million lower-income families that reported having no transaction account could well have had some other formal connection with a depository institution.

\section{Use of Financial Institutions by Lower-Income Families}

Our most sharply defined area of attention in this article is lower-income families with no direct connection to the mainstream system of banking and finance. These families would require the most attention by programs promoting the use of checking and savings accounts and electronic payment. These families will be found among those with no transaction accounts.

About 13 percent of lower-income families in the 1995 SCF said that they did not have any accounts or loans with financial institutions nor did they "regularly" conduct any personal financial business through financial institutions (table 2). Thus, of the 11 million or so lower-income families without a transaction account in 1995, about 1.5 million had little or no contact of any kind with financial institutions (see appendix B for a further discussion of these data and their limitations)

Individuals who report regularly doing business with a financial institution may be relatively more

2. Financial institutions used regularly by lower-income families, by status of transaction account ownership, 1995 Percent

\begin{tabular}{|c|c|c|c|}
\hline Institution & $\begin{array}{l}\text { All } \\
\text { lower- } \\
\text { income } \\
\text { families }\end{array}$ & $\begin{array}{c}\text { Has } \\
\text { transaction } \\
\text { account }\end{array}$ & $\begin{array}{c}\text { Has no } \\
\text { transaction } \\
\text { account }\end{array}$ \\
\hline Any ${ }^{1}$ & $86.6^{2}$ & 100.0 & $44.4^{2}$ \\
\hline $\begin{array}{l}\text { Depository institution } \ldots \\
\text { Commercial bank }\end{array}$ & 97.6 & 99.8 & 81.8 \\
\hline or trust company & 78.7 & 82.3 & 52.6 \\
\hline Thrift institution ..... & 23.1 & 23.5 & 20.1 \\
\hline Credit union $\ldots$. & 25.4 & 25.7 & 22.9 \\
\hline Finance or loan company & 17.5 & 16.9 & 22.2 \\
\hline Vehicle finance company & 1.2 & 1.1 & 1.3 \\
\hline $\begin{array}{l}\text { MEMo: Median umber of financial } \\
\text { institutions used }{ }^{2} \ldots \ldots \ldots \ldots \ldots \ldots\end{array}$ & 2 & 2 & 1 \\
\hline
\end{tabular}

Note. See general note to table 1 .

1. Percentages of respondents using particular types are for those using an institution.

2. Includes unspecified regular use of one or more unidentified financial institutions; see appendix B. 


\section{Account Ownership over Time}

Estimates of account ownership rates have varied between 1977 and 1996 by data source, definition of account holding, and timing of the study (table). Nonetheless, one can compare findings from the same surveys-for example, the Survey of Consumer Finances (SCF) conducted in 1983, 1989, 1992, and 1995 or the Panel Study of Income Dynamics (PSID) conducted 1984, 1989, and 1994. ${ }^{1}$

In the SCF data, ownership rates apparently decline from 1983 to 1989 , rise during the 1989-92 period, and then hold steady from 1992 to 1995 . In the PSID data, however, ownership rates for roughly the same periods seem to rise to a peak in 1989 and decline thereafter.

Because the PSID data are longitudinal (covering the same respondents over time) rather than cross-sectional (as are the SCF data), one can examine the rate at which

1. The SCF is conducted by the Board of Governors of the Federal Reserve System (see text note 1), and the PSID is conducted by the University of Michigan Survey Research Center. The Board conducted a Survey of Consumer Finances in 1986, as well, but, among other differences, it was of more limited scope. families with the same head of household have retained their accounts over time. ${ }^{2}$

Among families with the same head of household between 1984 and 1989, account ownership was fairly high and steady throughout the period at about 83 percent (data not shown). Among families with the same head of household between 1989 and 1994, however, ownership had dropped by the end of the period, to about 80 percent.

The pattern of ebb and flow in ownership during the two periods is as follows: Of households with an account in 1984, 6 percent no longer had one in 1989; conversely, of households without an account in 1984,8 percent had acquired one by 1989. In contrast, the figures for the 1989-94 period are 9 percent losing account ownership and 6 percent acquiring account ownership.

2. Erik Hurst, Ming Ching Luoh, and Frank Stafford, "The Wealth Dynamics of American Families, 1984-94," Brookings Papers on Economic Activity, 1:1998, pp. 267-338; see the discussion on pp. 299-301 on transaction accounts.

Surveys with data on ownership of checking and savings accounts

\begin{tabular}{|c|c|c|c|c|}
\hline Survey & Sample type & Year & $\begin{array}{c}\text { Measure of } \\
\text { account ownership }\end{array}$ & $\begin{array}{l}\text { Account } \\
\text { ownership } \\
\text { (percent) }\end{array}$ \\
\hline $\begin{array}{l}\text { Consumer Credit Survey, Board of } \\
\text { Governors of the Federal Reserve System }\end{array}$ & $\begin{array}{l}\text { National probability sample; cross } \\
\text { section; personal interview }\end{array}$ & 1977 & Checking or savings account & 91 \\
\hline $\begin{array}{l}\text { Survey of Consumer Finances, Board } \\
\text { of Governors of the Federal Reserve System }\end{array}$ & $\begin{array}{l}\text { National probability sample plus } \\
\text { oversampling of wealthy } \\
\text { households; cross section; personal } \\
\text { interview }\end{array}$ & $\begin{array}{l}1983 \\
1989 \\
1992 \\
1995\end{array}$ & $\begin{array}{l}\text { Checking, savings, or money market } \\
\text { deposit account, money market mutual } \\
\text { fund, or call/cash account at brokerage }\end{array}$ & $\begin{array}{l}87.5 \\
85.5 \\
87.1 \\
87.6\end{array}$ \\
\hline $\begin{array}{l}\text { Panel Study of Income Dynamics, Survey } \\
\text { Research Center, University of Michigan }\end{array}$ & $\begin{array}{l}\text { Began as national probability sample; } \\
\text { longitudinal data follow all members } \\
\text { of original households; personal } \\
\text { interview }\end{array}$ & $\begin{array}{l}1984 \\
1989 \\
1994\end{array}$ & $\begin{array}{l}\text { Checking, saving, or money market } \\
\text { account, nonstock individual } \\
\text { retirement account, or Treasury bills }\end{array}$ & $\begin{array}{l}80.8 \\
81.2 \\
77.8\end{array}$ \\
\hline $\begin{array}{l}\text { Survey of Consumers, Survey Research } \\
\text { Center, University of Michigan }\end{array}$ & $\begin{array}{l}\text { National probability sample; cross } \\
\text { section; telephone interview }\end{array}$ & $\begin{array}{l}1984 \\
1996\end{array}$ & Checking or savings account & $\begin{array}{l}92 \\
90\end{array}$ \\
\hline
\end{tabular}

willing to consider opening an account with that institution when changes in the payment system make an account more attractive. Consumers without accounts who do not regularly use financial institutions may be relatively less willing to open an account when these changes arise.

A helpful initiative in terms of broadening the involvement of lower-income families with mainstream financial services has been the creation of "community development financial institutions" (CDFIs) to serve lower-income neighborhoods. Since their widespread rise in the 1990s, CDFIs have been providing housing and business lending, consumer financial services (such as checking and savings accounts and home improvement loans), credit counseling, and business planning assistance. CDFIs can take the form of community development banks, community development credit unions, community development loan funds, microenterprise funds, and venture capital funds. ${ }^{4}$

\section{Reasons for Not Having a Checking Account}

The 1995 SCF asked respondents without checking accounts to state their "most important" reason for

4. See David Saunders and David Stoesz, "Welfare Capitalism in a Global Economy: The American Experience," Virginia Commonwealth University (paper prepared for the Symposium on Financial Services in a Post-Welfare-Reform Society, Federal Reserve Bank of Richmond, April 1998). CDFI customers and their financial practices are a promising area of study for insight into broader issues regarding the finances of lower-income families. 


\section{Some Characteristics of Low- to Moderate-Income Families}

Low- to moderate-income (lower-income) families differ from families overall in a number of respects (table). Lower-income families tend to be older and to include a higher proportion of minorities and of family heads who are single females.

On average, lower-income families have less education than the U.S. population as a whole: Three out of ten lower-income families are headed by individuals with less

Demographic characteristics of U.S. families, 1995

Percent except as noted

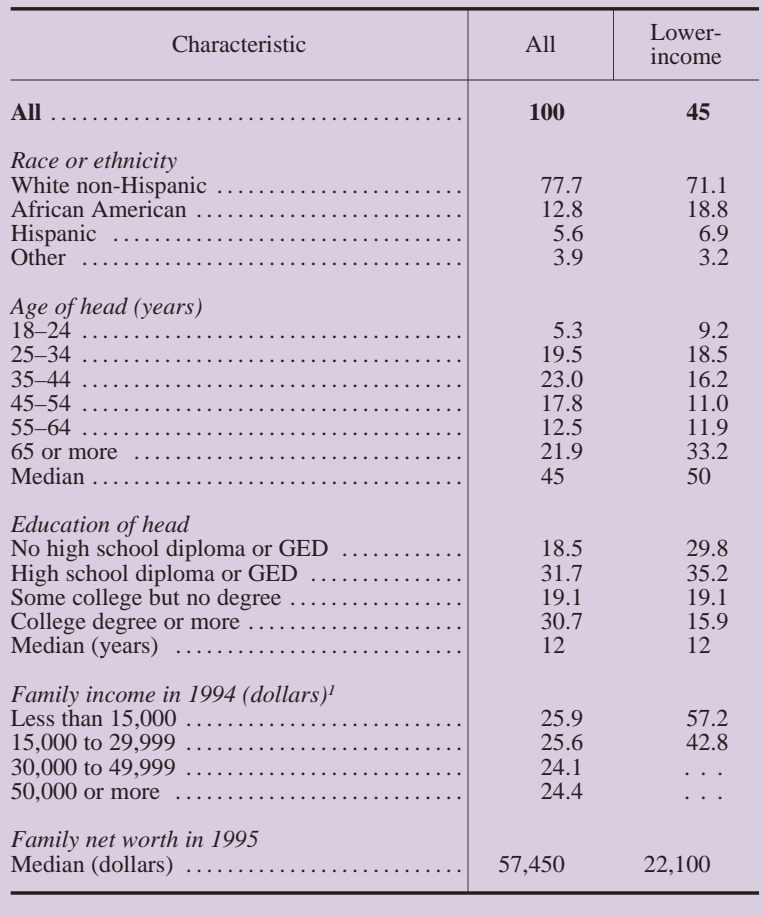

than a high school education, and one-third of the heads of families have only a high school education. Lower-income families also have lower net worth-a median of $\$ 22,100$ in 1995 compared with $\$ 57,450$ for all families (although, as measured, the lower-income group may include some wealthy families that happen to have a temporarily low current income). Lower-income families are less likely to be homeowners and are less likely to be employed.

Demographic characteristics-Continued

\begin{tabular}{|c|c|c|}
\hline Characteristic & All & $\begin{array}{l}\text { Lower- } \\
\text { income }\end{array}$ \\
\hline \multicolumn{3}{|l|}{ Marital status and sex of head } \\
\hline Married or living with partner.. & 52.4 & 30.2 \\
\hline Single female...$\ldots \ldots \ldots \ldots$ & 28.5 & 47.2 \\
\hline Single male $\ldots \ldots \ldots \ldots \ldots \ldots$ & 13.3 & 16.9 \\
\hline \multicolumn{3}{|l|}{ Family size (number of persons) } \\
\hline Median ...................... & 2 & 2 \\
\hline \multicolumn{3}{|l|}{ Housing status } \\
\hline Homeowner .. & 64.7 & 49.6 \\
\hline Renter or other $\ldots \ldots \ldots \ldots \ldots \ldots$ & 35.3 & 50.4 \\
\hline \multicolumn{3}{|l|}{ Current employment status of head } \\
\hline Employed $\ldots \ldots \ldots \ldots \ldots \ldots$ & 67.8 & 49.1 \\
\hline Retired $\ldots \ldots \ldots \ldots \ldots \ldots \ldots$ & 17.9 & 26.0 \\
\hline Unemployed or laid off . & 4.0 & 6.3 \\
\hline Other not employed ... & 10.3 & 18.6 \\
\hline \multicolumn{3}{|l|}{ Region of residence } \\
\hline Northeast .......... & 19.8 & 19.9 \\
\hline North Central & 24.0 & 23.7 \\
\hline South $\ldots \ldots \ldots$. & 35.1 & 34.9 \\
\hline West ......... & 21.1 & 21.5 \\
\hline \multicolumn{3}{|c|}{$\begin{array}{l}\text { Note. See general note to table } 1 . \\
1 . \text { These data will not match values cited in the text for median income, } \\
\text { which are from the Bureau of the Census, Current Population Survey (see } \\
\text { appendix A). } \\
\text { GED General education diploma. } \\
\text {. . . Not applicable. }\end{array}$} \\
\hline
\end{tabular}

checks" was cited distinctly more frequently than other explanations as the most important reason for not having a checking account. Among the remaining two-thirds, who did not make regular use of financial institutions, the most prominent primary reason for not having a checking account was "don't have enough money."

Other studies have also found that lack of money was cited as the main reason for not having an account. A 1996 Treasury survey of recipients of federal benefit checks such as those for social security and Supplemental Security Income found that, of the roughly 20 percent that did not have a checking or savings account, about half cited "don't have enough money" as the primary reason.

In a 1996 survey of low-income families, the most accounts, or unspecified regular personal business (table 3). Among these families, “don't write enough 
3. Lower-income families without checking accounts, distributed by reasons given and by status of financial institution usage, 1995

Percent

\begin{tabular}{|c|c|c|c|}
\hline Reason & All & $\begin{array}{c}\text { Uses } \\
\text { financial } \\
\text { institution }\end{array}$ & $\begin{array}{c}\text { Does not } \\
\text { use } \\
\text { financial } \\
\text { institution }\end{array}$ \\
\hline Any & 100 & 36.3 & 63.6 \\
\hline Don't write enough checks. & 26.2 & 31.6 & 23.1 \\
\hline Don't have enough money & 25.5 & 12.6 & 32.9 \\
\hline Don't like dealing & & & \\
\hline with banks . & 20.5 & 21.4 & 20.2 \\
\hline Cost factors $^{1} \ldots$ & 17.0 & 19.9 & 15.4 \\
\hline Practical factors ${ }^{2}$ & 10.0 & 13.2 & 8.1 \\
\hline $\begin{array}{l}\text { No depository institution } \\
\text { with convenient hours } \\
\text { or location ............ }\end{array}$ & $*$ & $*$ & $*$ \\
\hline
\end{tabular}

NotE. See general note to table 1.

1. Includes minimum balance too high, service charges too high, must keep balances low because of welfare.

2. Includes can't manage or balance checking account, haven't gotten around to it, don't need or want checking account, use alternative checking source, checkbook has been lost or stolen.

* Number of respondents too few to be meaningful.

frequently cited main reason was "no savings" followed by "bank account fees too high" and "banks require too much money just to open an account." 5 Anecdotal evidence indicates that concern over attachment of funds to satisfy court judgments regarding debt, child support, or other payments is another reason families do not have accounts. Although this response has appeared only rarely in most surveys to date, one out of five respondents without a checking account in the 1996 low-income survey indicated that wanting to "keep our financial records private" was their primary reason for not having an account.

The frequencies with which all families have cited certain explanations as the main reason for not having a checking account have changed between the 1989 and 1995 SCF. "Don't write enough checks" remained the most frequently cited main reason, but the proportion of families giving this response fell about one-fifth. The proportion of families citing "do not like dealing with banks" as the main reason rose about one-half, and the proportion citing "can't manage or balance a checking account" as the main reason rose about four-fifths. ${ }^{6}$

5. John Caskey, Lower-Income Americans, Higher-Cost Financial Services (University of Wisconsin-Madison: Filene Research Institute, Center for Credit Union Research, 1997), table 3.

6. Kennickell, Starr-McCluer, and Sundén, "Family Finances in the U.S." (see section on "Families without a Checking Account," p. 7).

\section{Other Financial Products and Services Used by Lower-Income Families}

Besides a checking account, a major credit card was the most widely held financial product among lowerincome families (table 4). ${ }^{7}$ Although holdings of savings and investment products were not widely reported by lower-income families, more than half of them reported having term or whole-life insurance (table 1). Nearly half of lower-income families were homeowners; of these, more than one-third had first mortgages on their homes, while about 5 percent had some type of second mortgage.

Not surprisingly, holdings of other financial products vary by ownership of a deposit account (table 4). Lower-income families with a deposit account are more likely to have a major credit card, a first mortgage, and a vehicle loan, and they are more likely to have insurance and term savings such as certificates of deposit. ${ }^{8}$

7. For these families, the average interest rate was 14.9 percent, and the average credit limit was $\$ 8,400$. Just over half of lowerincome families with credit cards carried a balance, the median of which was $\$ 1,300$. These results indicate use comparable to that of U.S. families as a whole: The average interest rate for all SCF families was 14.5 percent, and the average total credit limit was $\$ 13,000$; for the 59 percent who carried a balance, the median amount was $\$ 1,500$.

8. Other factors also affect the likelihood that a lower-income family will have such products and accounts. See also Jeanne M. Hogarth and Kevin H. O'Donnell, "If You Build It, Will They Come? A Simulation of Financial Product Use among Low-to-Moderate Income Families," Proceedings of the Association for Financial Counseling and Planning Education (November 1998), pp. 146-54.

4. Ownership of financial products by all families, and by lower-income families by status of transaction account ownership

Percent

\begin{tabular}{|c|c|c|c|c|}
\hline \multirow[b]{2}{*}{ Product } & \multirow[b]{2}{*}{$\begin{array}{l}\text { All U.S. } \\
\text { families }\end{array}$} & \multicolumn{3}{|c|}{ Lower-income families } \\
\hline & & All & $\begin{array}{c}\text { Has } \\
\text { transaction } \\
\text { account }\end{array}$ & $\begin{array}{c}\text { Has no } \\
\text { transaction } \\
\text { account }\end{array}$ \\
\hline \multicolumn{5}{|l|}{ Credit } \\
\hline Major credit card ${ }^{1}$ & 66.5 & 44.6 & 56.2 & 7.7 \\
\hline Loan & & & & \\
\hline First mortgage & 38.7 & 18.1 & 21.3 & 8.1 \\
\hline Vehicle & 30.8 & 18.6 & 20.0 & 14.1 \\
\hline Education & 11.8 & 10.6 & 10.7 & 10.2 \\
\hline Consumer & 14.2 & 13.5 & 13.9 & 12.1 \\
\hline \multicolumn{5}{|l|}{ Savings and investment } \\
\hline Certificate of deposit & 14.3 & 12.9 & 16.5 & * \\
\hline IRA or Keogh account & 26.1 & 12.1 & 15.7 & * \\
\hline Life insurance & 71.9 & 55.0 & 61.5 & 34.0 \\
\hline
\end{tabular}

Note. See general note to table 1 .

1. Discover, MasterCard, Optima, and Visa.

IRA Individual Retirement Account.

* Number of respondents too few to be meaningful. 


\section{Cross-Use of Checking Accounts and Check Cashing Outlets}

Many families with bank accounts also use check cashing outlets and various retail stores to obtain cash, and many families without accounts use banks for cashing checks. The 1996 survey by Treasury asked families where they cashed their benefit checks. Banks were most commonly cited (88 percent reported using them); even among families without accounts, 58 percent reported cashing their checks at a bank. Among all respondents, nearly one-fourth used grocery stores, 8 percent used check cashing services, and 2 percent used other retail stores. When questioned about their willingness to have their payments electronically deposited, some account-holding check recipients said that having their checks mailed gave them greater certainty about the arrival of payments and about resolving errors. ${ }^{9}$

A 1996 survey of low-income families with and without accounts found that about half (48 percent) of the respondents cashed checks at depository institutions and 17 percent used check cashing outlets. ${ }^{10}$ The same survey revealed that one out of seven account holders used check cashers. Looking at the opposite case, survey and trade association data indicate that about half to two-thirds of consumers who use check cashers may have checking accounts. ${ }^{11}$

\section{GROWTH OF ALTERNATIVE FINANCIAL SERVICES}

The number of check cashing outlets in the United States has grown sharply over the past decade or so, from about 2,100 in the mid-1980s to about 6,000 in 1997 (the latest year measured). The expansion, roughly on the order of 9 percent per year, has generated several attempts at explanation.

9. U.S. Department of the Treasury, Mandatory EFT Demographic Study, OMB 1510-00-68, Financial Management Service (1997), pp. 57-60. The average income of recipients still receiving their payments by check was $\$ 19,700$; seven out of ten were white, and nearly four out of ten had less than a high school education.

10. Caskey, Lower-Income Americans, Higher-Cost Financial Services, tables 3 and 5 . The results of this survey differ from those in the Treasury study primarily because Treasury surveyed federal benefit check recipients, a sample that contains virtually all income groups. An indication of the transactions needs among the low-income in this study is that, among those who used check cashing outlets ten or more times per year, 37 percent purchased between eleven and thirty money orders per year, and 35 percent purchased more than thirty.

11. The survey is in Sherrie Rhine and Maude Toussaint, "The Use of Formal and Informal Markets Among Black Families," Consumer Interest Annual, vol. 45 (forthcoming).
Some attention has been given to changes in the number of branches and community banks in the midst of growth in mergers and acquisitions. As noted, however, surveys do not reveal a noticeable problem with the location or hours of depository institutions for those without accounts. Moreover, access to the financial mainstream is clearly not the issue for the many users of alternative financial services who have transaction accounts.

Recent work on the effects of consolidation in the banking industry has some bearing on the analysis of changes in the market for financial services. A study employing a newly constructed database covering banking consolidation and neighborhood characteristics for 1975-95 found that the number of banking offices rose about 30 percent over the period. In general, the number of offices per capita in higherincome areas increased while the number in lowerincome areas decreased. By 1995, the number of banking offices per capita was roughly constant across neighborhood income categories. ${ }^{12}$

A second study, employing an updated version of the database and covering 1993-97, looked at the effect of consolidation on home-purchase lending to minority and lower-income borrowers and neighborhoods. It found that, after consolidation, banking organizations decreased home-purchase lending in some areas and increased it in others; independent mortgage companies and credit unions also increased their activity in some areas. The net effect was that consolidation caused no significant change in such lending to minority and lower-income borrowers and neighborhoods, but at the end of the period, more than half of all home-purchase loans were being made by offices outside the borrower's local community. ${ }^{13}$ Although the potential ease of obtaining a mortgage from an institution located outside one's neighborhood would seem to be greater than that of cashing a check outside one's neighborhood, the data suggest that conclusions about the effects of bank consolidation are not obvious or straightforward.

Another theory is that the mix and fee structure of products and services offered by banking organizations have become less attractive to lower-income families than the offerings of the alternative financial

12. Robert B. Avery, Raphael Bostic, Paul S. Calem, and Glenn B. Canner, "Changes in the Distribution of Banking Offices," Federal Reserve Bulletin, vol. 83 (September 1997), p. 723.

13. Robert B. Avery, Raphael Bostic, Paul S. Calem, and Glenn B. Canner, "Trends in Home Purchase Lending: Consolidation and the Community Reinvestment Act," Federal Reserve Bulletin, vol. 85 (February 1999), pp. 81-102. 


\section{Where Can I Cash This Check?}

Policies and charges for check cashing vary widely but generally hold regardless of the type of check (governmental, payroll, or personal). The examples below involve a check written either by, or to, the person presenting it ("second-party" checks) and do not necessarily apply to checks written to someone else and endorsed on the back for payment to the presenter ("third-party" checks).

- When a bank customer presents a second-party check at his or her bank and wishes to receive an equivalent amount of cash, the bank will issue the cash only if it is already available in the customer's account or through a credit line. In that case, the customer is not actually "cashing" the check but is simply depositing it and simultaneously withdrawing cash that was already available.

If the cash is not available, the customer must generally wait at least one business day as the check passes through the payment system before gaining access to the check's funds. The Federal Reserve's Regulation CC on funds availability determines the maximum length of time that a bank may hold the funds under varying circumstances. The majority of banks generally do not use the full hold periods available to them.

- Credit unions often give their customers instant availability of the full amount of a second-party check for amounts that may exceed the customer's current account balance or credit line.

- Many depository institutions will not cash a check presented by someone who does not have an account with the institution, and those that do often charge a fee. The fee may be limited by state law.

- Grocery stores often will allow their customers to write a check for the amount of purchase plus an extra amount returned in cash (generally no more than $\$ 25$ to $\$ 50$ ).

- Grocery stores may allow customers to cash secondparty checks free of charge with a minimum purchase.

- Check cashing outlets will charge either a flat fee or a fee based on the value of the check; the fees may be capped by state law at a certain percentage of the check's value. In New York, for example, check cashers can charge no more than 1.4 percent of the value of the check.

A service provided by some check cashing outlets that is not available from depository institutions is the cashing of a check drawn on the presenter's account but carrying a date in the future. The service is known as "deferred presentment" because the check casher must defer its presentment of the check to the customer's bank until the date given on the check. The date may be a payday for the customer, or it may be the end of a hold period placed by the customer's bank on another check previously deposited. Some states consider deferred presentment to be a loan and hence require that customers receive Truth-in-Lending disclosures when the service is provided. Some other states limit the fee for the service. sector. For example, small short-term loans are a popular product in the alternative financial sector, where check cashers make funds immediately available to customers via the cashing of post-dated checks (also known as "payday loans" or "deferred presentment"). Except for cash advances on credit cards, such loans are generally not found in the mainstream financial sector (see box "Where Can I Cash This Check?"). Others contend that the factor bringing users to alternative service providers is not convenience but comfort; that is, users find that the alternative sector provides more person-to-person contact than mainstream institutions (a consideration sometimes called "high touch versus high tech"). ${ }^{14}$

The informal financial market - that is, family, friends, and social organizations-is also a significant source of credit and financial services to lowerincome families, especially in the face of financial shocks, although the dollars transacted are likely to

14. D. Fontana, "Need Seen to Teach the Poor About High-Tech Banking," American Banker, March 17, 1997. be relatively small. ${ }^{15}$ Three-fourths of families facing emergency expenses related to illness and three-fifths of families facing them because of unemployment have reported using some type of informal financing arrangement. Information that helps both borrowers and lenders in the informal market is often inexpensive to obtain relative to other markets.

\section{ALTERNATIVE AND MAINSTREAM FINANCIAL SERVICES: A COMPARISON OF COSTS}

Check cashing outlets generally charge a percentage of the amount of the check being cashed, often up to some maximum fee. Some states limit these fees; for example, at the 1.4 percent limit imposed in New York, the fee for cashing a $\$ 340$ check would be

15. See Rhine and Toussaint, "The Use of Formal and Informal Markets Among Black Families"; and Philip Bond and Robert Townsend, "Formal and Informal Financing in a Chicago Ethnic Neighborhood," Federal Reserve Bank of Chicago, Economic Perspectives, vol. 20 (July/August 1996), pp. 3-27. 
about $\$ 4.75$, which is nearly equal to the average monthly fee charged by banks and savings associations in 1998 for a noninterest "fee-only" checking account. ${ }^{16}$

\section{Check Cashing and Bill Paying}

According to some estimates, consumers relying on check cashers pay from $\$ 86$ to $\$ 500$ per year to cash checks and pay bills, while the cost would have been $\$ 30$ to $\$ 60$ had they used a bank where they held an account. ${ }^{17}$ Researchers often infer from this price difference that lower-income families are not sensitive to the price of financial services. Another possible explanation is that consumers do not realize how much more they are paying at check cashers than they would at a bank. Some surveys have found, however, that a large proportion of consumers are aware of the price difference and understand that the fees charged by check cashers depend on the size of the transaction. ${ }^{18}$

\section{Credit}

Consumers who obtain credit from alternative financial service providers may also pay higher fees than they would have through a depository institution. Most of the loans in question are payday loans for small amounts (generally in the $\$ 100$ to $\$ 500$ range) and for short periods (usually seven to fourteen days), although some can be for as long as sixty days; the borrower is often allowed to renew the loan for additional periods. Although the fees may seem low to the consumer (say, 15 percent up to a fee cap of $\$ 30$ for as much as a $\$ 500$ loan), the annual percentage rate (APR) of interest can be more than 1,000 percent. ${ }^{19}$ In these cases the customer might not

16. Board of Governors of the Federal Reserve System, Annual Report to the Congress on Retail Fees and Services of Depository Institutions (June 1999), table 1, p. 3. A fee-only account imposes a monthly fee but requires no minimum balance.

17. Joseph J. Doyle, Jose A. Lopez, and Marc R. Saidenberg, "How Effective Is Lifeline Banking in Assisting the 'Unbanked'?" Federal Reserve Bank of New York, Current Issues in Economics and Finance, vol. 4 (June 1998); Organization for a New Equality, Cash, Credit \& EFT '99: Reducing the Cost of Credit and Capital for the Urban Poor (Washington, D.C.: Organization for a New Equality, 1998).

18. Joan Koonce-Lewis, Roger Swagler, and John Burton, "LowIncome Consumers' Use of the Alternative Financial Sector," Consumer Interest Annual, vol. 42 (1996), pp. 271-74.

19. Jean Ann Fox, The Growth of Legal Loan Sharking: A Report on the Payday Loan Industry (Washington, D.C.: Consumer Federation of America, 1998). know or understand the APR while still being aware of the dollar amount paid for the loan. ${ }^{20}$

Consumers who use alternative financial service providers may not consistently receive federal Truth in Lending disclosures and other information that could help them make appropriate decisions regarding these loan products. For example, in examinations during the first nine months of 1998, the Tennessee Department of Financial Institutions found various violations at 53 percent of the state's licensed check cashing outlets, among the most frequent being failure under the Truth in Lending Act to make the required form of disclosure of the APR. ${ }^{21}$ The high rate of violations may have been an anomaly because 1998 was the first year of examinations under the state's Deferred Presentment Services Act, passed in 1997. Nonetheless, another implicit cost to users of alternative service providers in some states may be relative weakness in consumer protections and their enforcement.

\section{BASIC BANKING}

During the 1980s, various state legislatures and consumer groups began exploring the provision of lifeline or "basic banking" services to consumers. ${ }^{22}$ One of the first formal demands for basic banking was a 1984 petition filed with California's attorney general and state banking superintendent on behalf of a coalition of consumer groups. The petition asserted that recent developments in banking practices in California-including the requirement of a credit card to open a bank account-prevented low-income consumers from obtaining the services they needed. Although the petition was rejected by the California banking superintendent, the banking relationships and account features outlined in the petition became the model for other basic-banking initiatives.

20. A 1972 study of the so-called small small loan industry in Texas found that only 2.4 percent of consumers were aware of the APR, but two-thirds were aware of the dollar cost of their loan, and four-fifths believed that the small small loan companies charged more for loans than banks did (Thomas A. Durkin, A High Rate Market for Consumer Loans: The Small Small Loan Industry in Texas, Technical Studies of the National Commission on Consumer Finance, vol. 2, Government Printing Office, 1975).

21. See Tennessee Department of Financial Institutions, Report to the 101st General Assembly on the Deferred Presentment Services Act (January 1999); for example, instead of carrying the APR to at least the required two places to the right of the decimal, some licensees rounded it to the nearest whole number. See also Robert E. Smith, "Payday Loaners Sued," Chicago Defender, March 23, 1999, p. 1.

22. See, for example, Glenn Canner and Ellen Maland, "Basic Banking," Federal Reserve Bulletin, vol. 70 (April 1987), pp. 255-69. 
Basic banking is broadly considered to consist of a minimum level of financial services that should be available to all. In an October 1986 policy statement, the FFIEC encouraged efforts by trade associations and depository institutions to offer "basic financial services, consistent with safe and sound business practices," and specified three elements of such services: a safe and accessible place to keep money, a way to obtain cash (including, for example, the cashing of government checks), and a way to make thirdparty payments. ${ }^{23}$

At the state level, different models of basic banking have emerged. State laws in Illinois, New Jersey, and New York outline account features and set specific fees and limits. Vermont's law encourages banks operating in the state to provide basic banking accounts. Rhode Island and Minnesota require banks to offer savings accounts at no charge provided that the balance is above a given threshold. ${ }^{24}$ Massachusetts implemented a voluntary basic-banking program in 1994 that encourages banks in the state to offer low- or no-cost accounts to lower-income families.

Many banks in basic-banking states, and in other states as well, offer services priced below the caps set by the states. For example, in a 1997 survey, the Consumer Bankers Association found that 36 percent of institutions offered a low-cost "ATM-only" account, and 70 percent offered a low-priced account for certain groups, such as senior citizens or students. Eighty percent of banks, savings and loan associations, and savings banks surveyed indicated that they have a basic "economy" checking account that offers limited service at a lower cost than "regular" checking accounts. Of these economy accounts, 76 percent had a fixed fee that averaged $\$ 3.66$ per month with no minimum balance requirement. For the three-fourths of these accounts with a check fee, the average number of checks that could be written per month without a fee was about eight, and the fee for each check over the limit averaged $\$ 0.59$.

The American Bankers Association's 1998 survey of retail banking found that 48 percent of small banks, 58 percent of midsized banks, and 69 percent

23. The member agencies of the Federal Financial Institutions Examination Council (FFIEC) are the Board of Governors of the Federal Reserve System, the Federal Deposit Insurance Corporation, the Office of the Comptroller of the Currency, the Office of Thrift Supervision (formerly, the Federal Home Loan Bank Board), and the National Credit Union Administration.

24. Illinois's and Rhode Island's laws were passed in 1986, Vermont's in 1987, New Jersey's in 1994, and Minnesota's and New York's in 1995. Pennsylvania had a basic-banking law in the late 1980s but repealed it in 1995 . of large banks offered a "basic/no frills" checking account. The average monthly fee was $\$ 3$, and most of the banks allowed between eight and ten checks per month before charging a per-check fee; the median per-check fee was $\$ 0.50$.

Some critics point out that depository institutions are doing little marketing, if any, to promote their basic banking accounts, and that without such marketing, many lower-income consumers without accounts will not know the basic accounts exist. A 1996 survey of financial institutions in New York City found no signage about the availability of basic banking accounts at any of the eighty-three branches of the thirty banks surveyed. ${ }^{25}$ The survey found that brochures on basic banking accounts were available at only 40 percent of the branches; and staff members at 40 percent of the branches failed to mention the availability of the basic banking account to the surveyors. Critics also contend that a policy followed at some banks to obtain a consumer's credit report in the deposit account application process discourages some consumers from seeking accounts at mainstream financial institutions.

A recent study concludes that low-cost accounts, characterized by low minimum deposits and low monthly fees, have had limited success in drawing the unbanked into the mainstream financial sector. ${ }^{26}$ The potential cost of a bank account includes more than the monthly fee or minimum balance requirements, however, especially for lower-income families who may face a high probability of overdrawing the account or of depositing a "bad" check. The costs of such events are not trivial: In 1998 the average charge by banks and savings associations for NSF (not sufficient funds) checks written by the customer was approximately $\$ 17$, whether the check was paid by the institution or returned unpaid. On the deposit side, about three-fifths of banks and four-fifths of savings associations charged a fee for deposit items returned; these fees averaged about $\$ 5.50$ at banks and about $\$ 7.50$ at savings associations. ${ }^{27}$

Hence, even on the grounds of price competition, basic-banking accounts may not be competitive with alternative providers when the total cost of use expected by a lower-income customer is considered.

25. Chris Meyer and Tracy Shelton, Buried Treasure: A Survey of New York City Banks Shows "Lifeline Law" to be Best-Kept Consumer Secret in New York (New York Public Interest Research Group, 1996).

26. Doyle, Lopez, and Saidenberg, "How Effective Is Lifeline Banking in Assisting the "Unbanked'?"

27. Board of Governors, Annual Report to the Congress on Retail Fees and Services of Depository Institutions, p. 10. 


\section{THE GOVERNMENTAL MOVE TOWARD ELECTRONIC PAYMENT}

In the mid-1990s, legislators turned their attention from basic banking to the electronic delivery of government payments. As a result of two federal laws, electronic payment methods were established for all needs-based, federally assisted programs-that is, food stamps and family welfare payments-and for all federal benefits, such as social security and veterans payments.

\section{Electronic Benefit Transfers}

In the early 1990s, pilot programs were established for electronic delivery of food stamp benefits and certain cash programs such as Aid to Families with Dependent Children (AFDC). Recipients used plastic cards and personal identification numbers to obtain food stamp benefits at point-of-sale (POS) terminals in grocery stores and cash benefits at automated teller machines and POS terminals.

The Personal Responsibility and Work Opportunity Reconciliation Act of 1996 established electronic delivery for food stamps and for payments under Temporary Assistance for Needy Families (TANF), the program that replaced AFDC. Under the law, all food stamp benefits will be delivered electronically by October 1, 2002.

A growing number of states-for example, New York, Maryland, and the members of the Southern Alliance of States-deliver food stamps and TANF benefits electronically. ${ }^{28}$ As part of the movement toward electronic benefit transfers (EBT), these and other states deliver state-level welfare benefits electronically as well. Some states have formed alliances with each other and with private-sector service providers to deliver these benefits, either through a debit card system or by encouraging clients to establish a direct deposit account at a financial institution. For program agencies, the electronic transfer of benefits offers significant advantages over paper-based delivery systems: It reduces the cost of benefit delivery, facilitates the management of program funds, and helps reduce fraud.

For recipients, the EBT program can provide greater convenience and security than the paperbased system because funds can be obtained or used more quickly, only as needed, and with greater pri-

28. The members of the Southern Alliance of States are Alabama, Arkansas, Florida, Georgia, Kentucky, Missouri, North Carolina, and Tennessee. Mississippi and West Virginia are considering joining the alliance. vacy; EBT can also lower the recipient's costs of obtaining benefits by eliminating check cashing and the associated fees. ${ }^{29}$ Despite the evidence that lower-income consumers who use the alternative financial services sector prefer high person-to-person involvement with financial transactions, recipients' experiences with EBT suggest that they may find a smooth transition to electronic financial services (see box "Methods of Doing Business with Depository Institutions"). ${ }^{30}$

During the early development of the EBT program, a major policy issue involved the level of consumer protections afforded to welfare recipients. State agencies expressed concern about the compliance costs associated with the Electronic Fund Transfer Act (EFTA) and its implementing rules (Regulation E), particularly in the areas of liability for unauthorized transfers and error resolution.

The Federal Reserve Board supported state and federal efforts to provide benefits electronically and sought to accommodate agency concerns while maintaining consumer protections. In 1995 the Board adopted a final rule for Regulation $\mathrm{E}$ that made some exceptions to facilitate compliance by state and federal agencies. At the same time, the Board determined that all consumers using electronic funds transfer services-including welfare recipients-were entitled to the same protections under the EFTA and Regulation E. The Board set a three-year period for voluntary compliance, after which the rules were to become mandatory. In response to states' concerns, however, the Congress exempted state-administered, federally assisted benefits from coverage under the EFTA in the Personal Responsibility and Work Opportunity Reconciliation Act of 1996.

\section{Electronic Transfer of Recurring Federal Benefits}

The Congress took electronic delivery of federal payments beyond the realm of welfare when it enacted the Debt Collection Improvement Act of 1996. A

29. Barbara Leyser, "Recipient Concerns with the Use of Electronic Benefit Transfer Systems for the Delivery of State and Federal Benefits," National Poverty Law Center, Clearinghouse Review, vol. 32 (September-October 1998), pp. 216-51.

30. See Josephine Swanson, Jeanne M. Hogarth, and Jane Baker Segelken, "Voices of Experience: Limited Resource Families and Financial Management," Proceedings of the Family Economics \& Management Conference (American Home Economics Association Meetings, 1993), pp. 13-28; and Jeanne M. Hogarth and Josephine Swanson, "Using Contemporary Adult Education Principles in Financial Education with Low Income Audiences," Family Economics \& Resource Management Biennial, vol. 1 (1995), pp. 139-46. 


\section{Methods of Doing Business with Depository Institutions}

In 1995, the most common method of doing business with depository institutions for all families with a transaction account was a teller visit; use of electronic methods was second, and the mail was third. About 75 percent of all families with transaction accounts used some form of electronic technology for their banking, and about 70 percent of lower-income families with accounts did so (table). ${ }^{1}$ Similarly, one-third of all families with accounts used automated teller machines (ATMs), while one-fourth of all lowerincome families did so. Sex, age, education, marital status, and region of residence also influenced the probability of ATM use.

The field of market research has shown that product innovation and diffusion follow a somewhat predictable pattern; and learning theory posits that, once consumers become comfortable with one technology, they are able to generalize and apply that learning to other technologies. Thus, one could expect to see growth over time in the proportions of families who use some of these technolo-

1. See Arthur B. Kennickell and Myron L. Kwast, "Who Uses Electronic Banking? Results from the 1995 Survey of Consumer Finances," Finance and Economics Discussion Series 1997-35 (Board of Governors of the Federal Reserve System, 1997), for a more detailed discussion of consumers' use of electronic technologies in banking. gies. ${ }^{2}$ For example, as families become familiar with direct deposit, electronic benefit transfers from welfare programs, or electronic transaction accounts, they may be more willing to use other electronic technologies for their banking.

2. Jeanne M. Hogarth, Kevin H. O’Donnell, Jinkook Lee, and Eun-Ju Lee, "Consumers' Use of Electronic Technologies in Financial Services: A View toward the 21 st Century," Consumer Interest Annual, vol. 45 (forthcoming).

Methods of doing business with depository institutions, for families with transaction accounts, 1995

Percent

\begin{tabular}{|c|c|c|}
\hline Method & $\begin{array}{l}\text { All U.S. } \\
\text { families }\end{array}$ & $\begin{array}{l}\text { Lower-income } \\
\text { families }\end{array}$ \\
\hline \multicolumn{3}{|l|}{ Electronic } \\
\hline Any ....... & 78.0 & 69.4 \\
\hline ATM & 35.3 & 25.7 \\
\hline Telephone & 26.8 & 16.7 \\
\hline Computer & 3.9 & 1.7 \\
\hline Direct deposit . & 53.4 & 14.0 \\
\hline Direct payment & 24.7 & 16.6 \\
\hline $\begin{array}{c}\text { ATM, telephone, } \\
\text { or computer }\end{array}$ & 50.5 & 36.3 \\
\hline Non-electronic & & \\
\hline Teller visits ... & 86.5 & 85.0 \\
\hline Mail .......................... & 58.6 & 40.0 \\
\hline
\end{tabular}

portion of the bill that became known as "EFT '99", declared that by January 2, 1999, the Department of the Treasury would have to use direct deposit for all recurring federal benefits, such as payments for social security, Supplemental Security Income, veterans benefits, and retirement. The primary motivation for this new law was to save tax dollars: A check costs the government $\$ 0.43$ to prepare and have delivered, while an electronic funds transfer costs only $\$ 0.02$.

Treasury's final rules for implementing EFT '99, issued in September 1998, stop short of mandating direct deposit. ${ }^{31}$ Instead, consumers have the choice of receiving their benefits through direct deposit; receiving a check; or using a special new account, the Electronic Transfer Account (ETA), which is scheduled to become available in late 1999. Between the July 1996 enactment of EFT '99 and April 1999, the proportion of recurring federal benefit payments delivered electronically grew from 58 percent of unit volume to 73 percent.

An additional effect of the law was to draw the attention of Treasury and other government agencies

31. Federal Register, "Management of Federal Agency Disbursements, 31 CFR 208,' September 25, 1998, pp. 51489-505. to families without direct deposit, including the relatively large number of lower-income benefit recipients without deposit accounts at financial institutions. Treasury's EFT '99 program fostered the formation of the Financial Services Education Coalition, a major community-based program involving other federal agencies, trade associations, and community groups, to help unbanked recipients choose and use financial accounts.

The coalition prepared a resource guide, Helping People in Your Community Understand Basic Financial Services, to provide community-based educators with information on planning, implementing, and evaluating EFT'99 education programs in their communities. ${ }^{32}$ Regional and state-level train-the-trainer

32. Members of the Financial Services Education Coalition are the American Association of Retired Persons, the American Bankers Association, the Board of Governors of the Federal Reserve System, Call for Action, the Consumer Information Center, the Credit Union National Association, the Federal Deposit Insurance Corporation, the Federal Trade Commission, the Independent Bankers Association of America, the National Association of Federal Credit Unions, the National Community Reinvestment Coalition, the National Consumers League, the National Foundation for Consumer Credit, the Organization for a New Equality, the U.S. Department of Agriculture's Cooperative States Research, Education, and Extension Service, and the U.S. Department of the Treasury's Financial Management 
and direct-to-consumer training sessions were held across the country to provide the type of one-to-one contact recommended by focus groups and survey participants. Trained staff from community-based organizations have worked with church groups, housing service providers, senior citizen groups, nutrition programs, and tribal councils to reach consumers with information on choices for receiving federal payments.

\section{Electronic Transfer Accounts}

Part of the EFT '99 legislation charged Treasury with ensuring access to an account at a depository institution for individuals affected by the electronic delivery mandate contemplated at that time. ${ }^{33}$ Through survey studies and focus groups, Treasury developed the ETA to be an account that would meet recipients' needs at a low cost.

On the basis of the studies as well as negotiations with financial institutions, Treasury determined that allowing no check writing with the ETA was reasonable given the greater potential for overdrafts and associated fees on the accounts. As announced by Treasury on June 30, 1999, some depository institutions will offer the ETA by late summer, and the accounts will have the following characteristics:

- Be available only at federally insured depository institutions to any individual receiving payments for federal benefits, wages, salary, or retirement through Treasury

- Carry the same protections afforded other account holders at the financial institution

- Accept electronic federal payments; the depository institution may allow other types of deposits

- Allow at least four withdrawals per month in any combination of ATM and over-the-counter (teller) transactions

- Allow at least four balance inquiries per month at an ATM or teller window

- Allow unlimited use with POS networks (including those permitting a cash-back feature) if available

- Carry a maximum fee of $\$ 3$ per month and a maximum overdraft fee of $\$ 10$

- Have no minimum balance except as required by federal or state law

- Provide a monthly statement.

Service. Copies of the guide and other education materials in English and Spanish are available at www.fms.treas.gov/eft/educ/ educmain.html or through Treasury's Financial Management Service.

33. Federal Register, "Electronic Transfer Account Notice," November 23, 1998, pp. 64820-25.
No additional features, such as checkwriting or electronic debits initiated by billers, will be allowed with or without an extra fee. Institutions may charge for balance inquiries and withdrawals above the minimum allowed; they may also charge for other services, such as card replacement and account research, at their customary rates. Depository institutions may choose to pay interest on ETA balances. Treasury will pay a one-time set-up fee to institutions for each ETA they open.

\section{ALTERNATIVE FINANCIAL SERVICE PROVIDERS AND ELECTRONIC BENEFIT PAYMENTS}

In Treasury's demographic survey, 8 percent of check recipients reported using check cashers; in the survey for the Center for Credit Union Research, 17 percent of low-income families reported using check cashers. As previously noted, the number of outlets has been growing fast, and the current market is large: The National Check Cashers Association (NaCCA), the trade association for 3,500 of the 6,000 check cashing outlets in the United States, estimates that their members annually cash about 180 million checks with a face value exceeding $\$ 55$ billion. ${ }^{34}$

The EFT '99 initiative has led check cashers to look for ways that federal check recipients could receive their benefits electronically through check cashing outlets. Under Treasury's definition of financial institution, check cashers are not eligible to offer deposit accounts or to receive electronic deposits directly from the government. Instead, some have developed arrangements with financial institutions to have consumers open an account and then move the account's funds into an intermediary account that consumers can access through check cashing outlets.

Under such "hybrid" arrangements, however, funds moved into the intermediary account are no longer covered by FDIC insurance or other federal protections, such as the EFTA and Regulation E. Consumer advocates have raised some concerns about the cost and safety of these arrangements. As a result, Treasury in early 1999 issued a request for comment on the possible need to regulate or prohibit such hybrid accounts.

34. National Check Cashers Association, Q\&A-NaCCA Facts, 1999 (www.nacca.org/q\&a.htm). Check cashers, pawn brokers, wire transfer companies, and other alternative financial service providers have been the subject of several studies over the past decade. See, for example, Jean Ann Fox, The High Cost of 'Banking' at the Corner Check Casher (Washington, D.C.: Consumer Federation of America, 1997); and John Caskey, Fringe Banking: Check-Cashing Outlets, Pawnshops, and the Poor (Russell Sage, 1994). 
In one of several partnership arrangements taking another approach, NaCCA has joined with a major depository institution to offer a debit card to individuals without bank accounts who frequently cash federal benefit or payroll checks at a check casher affiliated with NaCCA. Under the program, the individual receives a special account at the bank that allows debit-card purchases or ATM withdrawals at any NaCCA-member outlet in the country. The program is set for testing this summer.

\section{ASSET-BUILDING OPPORTUNITIES FOR LOWER-INCOME FAMILIES}

The ownership of savings instruments by lowerincome families is more limited than their ownership of checking accounts. ${ }^{35}$ The awareness is growing, however, that lower-income families could better their chances for income gains by building savings for home ownership, education, training, and entrepreneurship. As programs for EBT and for direct deposit of federal payments reach more people, the familiarity with mainstream financial institutions that is necessary for many of the unbanked to establish savings may grow as well.

Even with a greater willingness to deal with depository institutions, families receiving welfare benefits face a special problem in acquiring savings because of state limitations on asset holdings. A family whose income and assets are above particular levels will not qualify for welfare benefits. The allowable level of assets varies by state, and in some cases by region within the state, even for the federally assisted welfare programs (food stamps and TANF). In general, asset limits have been set in the range of $\$ 1,000$ to $\$ 2,000$. Many states have raised the limits and, along with the federal government, have begun to respond to the problem of savings with programs that will also tend to bring families without accounts into banking (see box "Asset Limits and Individual Development Accounts").

\section{CHALLENGES AND OPPORTUNITIES IN BANKING RELATIONSHIPS FOR LOWER-INCOME FAMILIES}

Treasury's EFT ' 99 initiative and the advent of the ETA may open new doors to basic banking services for federal benefit recipients. The marketing of the ETAs may also have spillover effects for those who are not recipients of a federal payment but who

35. See Michael Sherraden and Neil Gilbert, Assets and the Poor: A New American Welfare Policy (M.E. Sharpe, 1991).

\section{Asset Limits and Individual Development Accounts}

In 1996, Iowa became the first state to raise asset limits for welfare recipients and, for low-income families more generally, to test a new savings instrument, the Individual Development Account (IDA). ${ }^{1}$ The use of funds in an IDA is limited to education expenses, a first-time home purchase, or the start-up of a small business. In an IDA program, a household's deposits are matched, up to a limit, by funds from foundations and other sources. The matching funds are generally not counted as assets in considering a family's welfare eligibility.

Since 1996, thirty-five other states and the District of Columbia either provide for IDAs or have enabling legislation pending. Since Iowa's action in 1996, another thirty-eight states have raised their welfare-related limits on assets, some to as much as $\$ 10,000$. The Assets for Independence Act of 1998 reinforced the emphasis on asset building for lower-income households by providing additional resources for IDAs. Pending federal legislation would allow tax credits to financial institutions that provide matching funds on IDAs they open and would allow tax credits to organizations contributing funds to nonprofit organizations that administer IDA programs.

Improving the awareness of welfare recipients regarding eligibility limits could help them make the most effective use of IDAs. In a 1996 report, only 13 percent of welfare recipients surveyed correctly identified the $\$ 1,000$ asset limit of their state's welfare program; 84 percent thought the asset limit was $\$ 500 ; 3$ percent thought it was $\$ 2,000$. Such misunderstanding of welfare eligibility limits may be as much of a barrier to assetbuilding as the limits themselves. ${ }^{2}$

1. The IDA concept was introduced in Sherraden and Gilbert, Assets and the Poor (see text note 35). More information on IDAs is available from the Corporation for Enterprise Development, Washington, D.C. (www.cfed.org)

2. The data on knowledge of eligibility limits is in Julia Marlowe, Deborah Godwin, and Esther Maddux, "Barriers to Effective Financial Management Among Welfare Recipients," Advancing the Consumer Interest, vol. 8 (Fall 1996), pp. 9-13. See also John Caskey, Beyond Cash and Carry: Financial Savings, Financial Services, and Low-Income Households in Two Communities (Washington, D.C.: Consumer Federation of America, 1997).

become interested in a basic type of banking account because of the ETA marketing.

Nonetheless, many lower-income families are probably still without a deposit account and might benefit from the greater wealth-building potential that a banking relationship could offer. Moreover, evidence suggests that lower-income families are less informed about the financial marketplace than other families. Many may not know the choices they have among institutions and accounts, especially as new accounts and transaction products become available. Others may not clearly understand the long-term 
costs and the opportunity costs of the services they use. And families who qualify for welfare may not be aware of the higher asset limits offered by their states or their opportunity to build assets through IDAs.

While laws may provide the opportunity for lowerincome families to more fully use mainstream financial services, factors such as innovation, information, and education will play an important role in creating awareness of the choices available to these families. For example, for families without a checking account, the primary barrier to having one seems to be that they "don't write enough checks." Therefore, such families might see an advantage in an all-electronic account with access to low-cost money orders, debits, and direct payment for bill paying. Those that say they "don't have enough money" might find that low- or no-cost accounts offer advantages relative to check cashing outlets and other alternative financial service providers.

For lower-income families, account ownership seems to be as much a function of household characteristics as it is of account features and the other product offerings, services, and delivery systems of financial institutions. The move toward more electronic delivery of banking services may be fairly smooth for those lower-income families already using electronic benefit transfers for food stamp and TANF benefits and for those federal benefit recipients who sign up for an ETA. The theory of diffusion of innovation leads to the conclusion that, over time, more families will use these newer electronic technologies, and learning theory predicts that, with experience, families will use additional electronic technologies. For families without experience in using electronic technology, assistance from community educators and financial institutions can help them become more familiar with the technology and other considerations about bank accounts so that they might better assess their options.

Navigating the transition to an "all-electronic Treasury," evaluating account offerings at both mainstream and alternative financial sector providers, and helping lower-income families build wealth require a combination of policy development and education initiatives that target both sides of the marketplace. On the consumers' side of the market, lower-income families may need additional exposure to information and education if they are to choose accounts and products that fit their needs and to use electronic technologies to manage these accounts. On the firms' side of the market, financial institutions need to have appropriate products, services, delivery systems, and information available to consumers to enable them to more fully participate in the financial marketplace.

\section{APPENDIX A \\ MEASURING INCOME AND OWNERSHIP \\ OF CHECKING ACCOUNTS}

Agencies required to implement laws regarding lowto moderate-income households or families (referred to in the text as lower-income families) often define that income as being no more than 80 percent of the median income for the area or region of residence. This article combines data on median regional income from the Current Population Survey of the Bureau of the Census with data on family income from the Survey of Consumer Finances (SCF) to estimate the number of lower-income families in the United States. The Current Population Survey covers a sample population far larger than that of the SCF and offers a more stable base for estimating incomes nationally and regionally.

\section{Census Measure of Median Income}

To get data on each family's income for a full year, the SCF collects information on families' total cash income before taxes in the preceding calendar year. Hence, the 1995 SCF reports 1994 income. The present study distributes the SCF sample across the four regions of the United States as defined by the U.S. Bureau of the Census and compares the respondents' reported incomes with 80 percent of the 1994 median incomes that Census reported for those regions. These regions, their 1994 median incomes, and the corresponding 80 percent maximums for lower income are as follows:

- Northeast, $\$ 34,926$ and $\$ 27,940$

- Midwest, \$32,505 and \$26,004

- South, \$30,021 and \$24,016

- West, \$34,452 and 27,561.

Of the 4,299 families in the SCF, 1,372 (about 45 percent, weighted data) reported income in the low to moderate range of the regional Census data.

\section{Ownership of Checking Accounts}

Transaction accounts at financial institutions are checkable accounts and savings accounts as described in text note 2 .

In addition to questions about specific transaction accounts and other assets, the SCF asks respondents 
whether they or any family members living with them have a checking account. The interviewer does not limit the meaning of "checking account" in this question except to ask the respondent to exclude money market funds not used regularly as checking accounts. If the answer to the question is "no," the interviewer asks for the "most important" reason for not holding a checking account.

In this article, families that hold only other products (major credit cards, first mortgages, home equity loans, vehicle loans, education loans, consumer loans, certificates of deposit, IRAs and Keogh accounts, or life insurance) are considered separately from families owning transaction accounts to shed some light on possible interrelationships among holdings of financial products.

\section{APPENDIX B}

\section{MEASURING USE OF FINANCIAL INSTITUTIONS}

Little data beyond those in the Survey of Consumer Finances (SCF) indicate the number of families that make no use whatsoever of depository institutions, not even to cash checks. The data on this issue in the $\mathrm{SCF}$ are indicative, but the question on which they are based is not sharply drawn. Some detailed discussion of the question and possible answers is warranted to ensure that interpretations of the results are not too broad.

The SCF does not have any questions that specifically probe for the use of alternative financial service providers such as check cashing outlets nor for the use of banks for check cashing and other services by those without accounts or loans at banks. The question in the 1995 SCF that does touch on this issue asks, "With how many financial institutions do you and your family currently living here have accounts or loans, or regularly do personal financial business?" The respondents were asked to include "banks, savings and loans, credit unions, brokerages, loan companies, and so forth" but to exclude institutions at which they had only a credit card account or business loan. ${ }^{36}$

36. Question X305, 1995 SCF Codebook.
The families reporting that they had no financial institutions at which they had accounts or loans or regularly did personal financial business are the families categorized in this article as making no regular use of a financial institution (and being the most clearly "unbanked").

The SCF reconciles the "accounts or loans" aspect of the answers to the question with information collected from subsequent questions. For example, if a respondent answers "none" to the question "With how many financial institutions ..." and later reports having a loan or other account, the original answer is revised to reflect the new information.

The SCF has no follow-up questions, however, that would shed light on "regularly do personal financial business." Therefore, answers to this question from families without accounts are not as reliable as the answers regarding the "accounts or loans" aspect of the question from families with accounts. For example, a family may answer, say, "one or two" to the question "With how many financial institutions ..." If the family is subsequently found to have no accounts or loans, they are nonetheless assumed to conduct some unspecified regular personal financial business with a financial institution. No subsequent questions are asked to discover the nature of the use implied by the original answer. Conceivably, some respondents with no accounts or loans may consider, say, their regular purchase of stamps in a bank lobby as constituting regular business. On the other hand, some families without accounts or loans may answer "none" to the question even though they regularly cash checks at one or more banks. So the responses to the question may constitute both under-reporting and over-reporting of families with no accounts or loans who indicate that they regularly do personal financial business with a financial institution. 